\title{
Government Transparency: Reality or Mirage?
}

\author{
NoÉmia Bessa Vilela, Jose Caramelo Gomes \& Paulo Morais
}

\begin{abstract}
All citizens are entitled to access governmental information as, only if properly informed, that they can participate in politics. The right to information is enshrined in a number of international agreements, including Article 19 of the Universal Declaration of Human Rights. The right of citizens to access public authorities' information is called Freedom of information. This information plays a crucial role in informing the population so that they can make accurate political choices. The mere disposal of information is not enough, as much of public documents suffer from complex language and other technicalities that can prevent an informed use of the information. Thus, sites displaying information must be adapted in order to guarantee usability, functionality and accessibility; there must be different levels of information, as there are diverse groups of individuals with different skills. Such usability, functionality and accessibility require designing effective communications, paying attention to balancing the complexity that citizens can manage and the complexity that those responsible for the requested information are producing.
\end{abstract}

Keywords: • transparency $\bullet$ government $\bullet$ economics $\bullet$ human rights - IT

CorResPOndence AdDREss: Noémia Bessa Vilela, M.Sc., University Portucalense Infante D. Henrique, IJP- Portucalense Institute for Legal Research, R. Dr. António Bernardino de Almeida, 541/619|4200-072 Porto 15, Portugal, email: noemia@uporatu.pt. Jose Caramelo Gomes, Ph.D., Professor, University Portucalense Infante D. Henrique, IJP- Portucalense Institute for Legal Research, R. Dr. António Bernardino de Almeida, 541/619|4200-072 Porto 15, Portugal, email: caramelo.gomes@upt.pt. Paulo Morais, Ph.D., University Portucalense Infante D. Henrique, IJP- Portucalense Institute for Legal Research, R. Dr. António Bernardino de Almeida, 541/619|4200-072 Porto 15, Portugal, email: paulom@upt.pt.

https://doi.org/10.4335/15.3.725-736(2017)

ISSN 1581-5374 Print/1855-363X Online C 2017 Lex localis

Available online at http://journal.lex-localis.press. 

Mirage?

\section{Introduction}

All citizens are entitled to access governmental information as, only if properly informed, that they can participate in politics. The right to information is enshrined in a number of international agreements, including Article 19 of the Universal Declaration of Human Rights. The right of citizens to access public authorities' information is called Freedom of information. This information plays a crucial role in informing the population so that they can make accurate political choices.

The World Bank and the European Union are some of the international organizations that have being actively promoting government transparency. Several countries have been adopting measures to promote transparency, namely widening the access to information and adopting access to information legislation (Relly and Sabharwal, 2009).

One of the main reasons presented to justify transparency in governments is to curtail corruption, as openness can stop misappropriations and conflicts of interest when public money spending is displayed before the eyes of the citizens.

Transparency is then used to keep government honest (Kierkegaard, 2009). However, the success of this effort is largely dependent on the social, political and cultural environment. It has been demonstrated that the nation's level of democratic development is highly correlated with values of good governance such as transparency, participation, and accountability (Harrison \& Sayogo, 2014).

Anti-corruption measures may be achieved by administrative reform, law enforcement or social change, when tolerant perceptions of corruption are tackled and changed (Bertot et al., 2010). In either case, the focus on information is foreseen as being essential.

Access to information can be either proactively promoted by governments, with different kind of mechanisms of disclosure and publication, or they may simply release information on request by civil organizations, media and citizens. Some countries have launched internet-based initiatives, like e-governments or public disclosure portals for making information available to the public. In Latin America, Transparency portals, typically an initiative of the local minister of Finance, are an example of how public information, in this case public financial information and procurement processes, is released (Solana, 2004; Matheus et al., 2010). The internet has greatly reduced the cost of collecting, distributing and accessing government information (Roberts, 2006), making it the master tool in this framework. In the past years, a new trend emerged in what concerns the increasing access to government records and greater focus on the proactive disclosure of information (Cullier and Piotrowski, 2009). 
Research suggests that there is positive effect of the implementation of e-governments in downgrading corruption (Anderson, 2009).

However, transparency in not a consensual concept and neither has it been receiving consistent attention from academics, although being a hot issue for political agents and media (Meijer, 2012). The importance of widely distributed and accessible government information is undeniable (Bertot et al., 2010), nonetheless several drawbacks have been pointed out to the total release of information. Bannister and Connolly (2011) list some problems that can rise from transparency in public administration, as cost provision and the risk of data misinterpretation or inadvertent release. Other concerns are national security and personal privacy, as the unreasoned disclosure of information can jeopardize sensible information or basic human rights (Coglianese, 2009; Piotrowski and Van Rizin, 2007).

Most of academic research has focused on government led initiatives to promote transparency, but civil organizations and citizens are also in the forefront when it comes to make public information available to the public. Several initiatives around the world, on a solo responsibility or under the umbrella of international projects, have been collecting and presenting public data.

OpenSpending is one of these projects, supported by the Open Knowledge Foundation, presenting datasets, monitoring and storing the financial operations of the governments. Several sites under the broad name of "Where does my money go?" have been launched in countries like the UK, Japan and Macedonia.

Although these last projects have not been widely studied, the literature addressing transparency and disclosure of public information has identified some gaps to be filled in by academic research that can apply for both government and citizen initiative, for instance, the assessment of the level and type of governmental transparency that is appropriate (Piotrowski and Van Rizin, 2007). Other questions are yet to be answered, such as: which sectors are becoming more transparent and does transparency changes the behaviour of civil servants and public organizations (Meijer, 2012). It is also said that here is a great need to publish reports reflecting the financial situation and the management policies adopted by public institutions (Munoz \& Bolivar, 2015).

Challenges for academic research addressing transparency and openness in public administration have been identified: a monitoring is needed in order to identify possible negative side effects (Meijer et al, 2012); government information must survive in an accessible format and location to provide for long -term transparency (Jaeger and Bertot, 2010). On the other side, the mere disposal of information is not enough, as much of public documents suffer from complex language and other technicalities that can prevent an informed use of the 

Mirage?

information. Thus, sites displaying information must be adapted in order to guarantee usability, functionality and accessibility; there must be different levels of information, as there are diverse groups of individuals with different skills. This usability, functionality and accessibility require designing effective communications, paying attention to balancing the complexity that citizens can manage and the complexity that those responsible for the requested information are producing.

\section{Justification of the question}

According to the Corruption Perception Index, over the past few years, Portugal has been improving with regard to its index of Corruption, or at least, what is perceptible corruption having escalated from the 31st place in 2014 to $28^{\text {th }}$ in 2015 amongst the most transparent countries of the 175 analyzed in 2014 and 167 in 2015 by the non-governmental organization "International Transparency".

When compared to the other European Union (EU) and Western Europe countries, Portugal is located at the 17th position. World Leadership has been shared by Denmark, Finland and Sweden.

The collected data shows that the phenomenon of corruption, when compared to European consorts, continues to play a dominant role in Portugal. This reality collides with the international commitments made by Portugal, as a signatory of the main international conventions against corruption such as "United Nations Convention against Corruption" and "The Convention on the Fight against Corruption of Foreign Public Officials in International Business Transactions OECD" and the current national legislation.

In practice, the undertaken commitments have not been developed - or rather fulfilled - as expected, in particular regarding the creation of specialized structures for fighting corruption and for the protection of those who act as whistleblowers of corruption.

Reality, in Portugal has been contributing to the generalization of the idea, amongst its citizens, that the effectiveness in combating this crime type is far from being effective. Actually becoming the exact opposite of what was expected by raising serious doubts regarding the political will to change the current paradigm as no effective measure have been enforced that aim at minimizing a phenomenon that "destroys the fundamental values of human dignity and political equality, making it impossible to guarantee the rights to life, personal dignity and equality, and many other rights" (Klitgaard, 1991:33).

One way of detecting corruption is by scrutinizing the use of public funds by governments. Being a member of the European Union, Portugal has launched 
administrative reforms in order to comply with new standards of governance and public disclosure of information. However, transparency has not been fully addressed, nor a comprehensive site on financial information has been launched, although there is no doubt on the importance to fight corruption and elevate integrity standards (Triães et al., 2011). The debate, from a political standpoint but also in terms of academic research, is then missing in Portugal and there is not a broad understanding on what transparency means and how to measure it in the Portuguese context.

Defining corruption can be considered to be an Herculean task. Its concept and perspective, following the society, have been changing over the decades, having been the object of attention by different authors, from different areas, who are trying to work out a definition of corruption that is considered to be final. The non-governmental organization Transparency International has defined corruption has been the abuse of entrusted power for private gain. It can be classified as grand, petty and political, depending on the amounts of money lost and the sector where it occurs.

Generally, we are facing corruption, when a "dominant" person who takes on an undue advantage for the rendering of a service. This action is nothing but criminal behavior. The Portuguese Criminal Code ${ }^{1}$ naturally states corruption as part of the exercise of public functions (Articles 372 to 374-A), although corruption may exist in various sectors of activity and such behavior should also be criminalized as, in criminal law, no analogy is acceptable which result in corruption being only and exclusively sanctionable within the public sector.

It is true, however, that in the public strand, is where there is being outlined an approach that consists in gathering legislation, case law and doctrine bot in a national and international perspective. From a legal perspective, the offense of corruption involves the combination of three actions:

- - An act or omission

- - The practice of a lawful or unlawful act

- - The consideration of an undue advantage for himself or for a third party.

Corruption can be either active or passive depending on whether the act or omission is committed by the person who corrupts or by the person who is corrupted by the "hands" of another author.

We refer to active public corruption when a person - directly or through another person, for himself or for another person -, makes an offer, a promise or provides benefits of any kind to a government official in order to motivate one, or refrain from fulfilling a particular act.sepe Active public corruption occurs when a public official asks for, accepts or receives, directly or indirectly - meaning through another person-, for himself or for someone else, an offer, promise or benefit of 

Mirage?

any kind to perform or abstain from performing a given act.

Corruption will be considered to be a lawful act if - the act or omission - is not contrary to the duties of those who are corrupt or corrupted. It so occurs in the way the result of corruption will be a clear violation of their duties, then we are facing corruption for having performed an unlawful act.

The decisive factor when it comes to the crime of corruption is the link between what is promised or delivered and the objective to be achieved, namely the adoption of a particular behavior. There is corruption, even if the act (or lack thereof), whether or not legitimate under the duties of the person concerned, has not taken place. The Portuguese Criminal law only allows attempts to be criminalized if so is codified.

Similarly, there is corruption whatever the nature, or value of the benefit. Klitgaard, presents the following definition of corruption: "la corrupción es el uso indebido de los ámbitos oficiales para la obtención de resultados no-oficiales, por lo general ventajas personales, aunquefrecuentemente sólo para el beneficio de la propia empresa o partido político. Puede ocurrir dentro de organizaciones públicas o privadas, puede abarcar tanto actos de omisión como decomisión, puede ser interna a una organización o involucrar clientes de la organización. Demanera análoga a otros problemas sociales tales como la polvición o una epidemia, la corrupción admite grados. Existe casi en todas partes y su profundidad difiere, como difiere eldaño social que provoca en cada caso. La corrupción es un delito calculado, no es el productode un momento de pasión (...) Corrupción $=$ monopolio + discrecionalidad - obligación derendir cuentas $" 2$ (Klitgaard, 1997, p.252).

The definition of corruption is a matter of great importance and should be the first step in order to prevent it from happening as you cannot prevent wat you do not know exists.

The human right to information

Until in 2009, it was adopted, in the Council of Europe the Convention on Access to Official Documents ${ }^{3}$, international human rights instruments did not provide for any particular protection to the right to information, nor foresaw sanctions for its prevention. The effective, and we should say long lasting process of recognizing the right to information in international human rights law was low to evolve. The current reality is quite different as several international human rights organizations such as the UN Human Rights Committee, the Inter-American Court of Human Rights, the European Committee on Social Rights and the European Court of Human Rights have - all of them - accepted and advocated for the existence of a right to information in certain circumstances. It matters to say that, when we talk 
about free access to information, we refer, only, to public documents.

We cannot look at the right to information without, at the same time, taking a glace to Freedom of expression as they have long been linked in international human rights activities and documentation. Some case law as even considered that "Freedom of information is in the blood which runs in the veins of freedom of expression"4.

Even though these international instruments consecrate the right to information being supported by case law - a whole new question arises regarding the eventual - imposition of limits to the scope of the right to information.

These limitations, that, in the authors perspectives, either for security, nondisclosure policies or any other acceptable reason are to be applied, should not be understood as constraining the right to information. It Is generally so, when it comes from treaties, that rights do have, in general, limitations and even, in some pre-determined circumstances, be restricted. What is at issue here is the shape of the right to information in advance of the imposition of any legitimate restrictions on its operation. One of the pillar of democracy is equality, one of the main concepts of human rights. Democratic model of decision- making process would not be possible without protection and implementation of human rights (Ananiev \& Poposka, 2014).

\section{$4 \quad$ Solution}

After clearly defining the concept of corruption we can start focusing on transparency. Transparency, being worthy of particular attention, on its own can only be analyzed after it is made conceptually accurate as only such categorization, or definition, if you prefer, will enable ii to be scaled with overall accuracy. As it was addressed in our Chapter one, transparency in not a consensual concept and neither has it been receiving consistent attention from academics, although being a hot issue for political agents and media (Meijer, 2012).

Portugal has already addressed the issue of transparency, thus highlighting the public consciousness of public officials on the matter. However, these initiatives have not involved the national government and the major issues concerning the disclosure of critical information. For instance, a portal for municipal transparency, displaying financial and demographic indicators, has been launched ${ }^{5}$ (coincidently following an initiative of a non-governmental organization in the same matter ${ }^{6}$ ), but still has to be improved in what concerns the identification of the major public contractors or in the presentation of information that directly affects the public serviced provided to the locals. 

Mirage?

Therefore, a first step towards a more transparent government is the creation of a legal and regulatory framework that clearly defines the boundaries of the concept and the areas to which it may be applied. Considering the experiences that have taken place worldwide and the aim to tackle corruption, budgetary policy transparency should lead any initiative. Thus, considering that budgeting is one of the most critical and government wide open government applications (Puron-Cid, 2013) and that information systems have become central to budgeting operations in government, information and communication technologies play now a central role.

Better transparency processes can thus be achieved through the creation of a platform, to which may concur the knowledge raised from other main national and international platforms available online that, in any way, relate to the intentions monitoring transparency.

The goal of creating such a national platform would result in the maximization of the efficiency and extent of this initiative, without losing focus on the national reality, with its very own idiosyncrasies, which should be taken into consideration when adopting some of the ideas conveyed in other - international - platforms. There are multiple platforms that have been focusing on transparency ${ }^{7}$ and which should be subject to careful analysis that would expedite the construction of a Portal of transparency for the Portuguese Government, taking into consideration the countries specific needs.

The fact that information regarding such matter is scattered throughout several different platforms of transparency make is unknown and hence, not accessible to the general public, and in this particular case, national population.

This portal of transparency would work a tool that would aim at promoting broad access to relevant data on the use of public resources by the state. It should be presented in a readable and sense-making way to the general public, such as how much is the government spending in healthcare providing services, in education, in public works. If information if to be provided, but in a complex and obscure form, then it will have no appeal to the common citizen and the platform will not achieve its goal of improving transparency. Budgetary information, for instance, must be delivered in ways that show how public spending affects the everyday life of the citizens.

Thus, through the portal, any citizen might monitor the actions of direct and indirect administration and the management of public finances in a continuous, credible and updated way. Thus, it is urgent, at first instance, to predetermine all the information to be made available in a public portal.

- What information affects the governmental activity and available state that 
can be the subject of full and legitimate disclosure?

- What information should be made available to citizens having seen delivering real information?

- How can it work?

The first step would be to create a platform, an up to date online platform that would enable the access to public information that is to - as in mandatory - be made available to the general population. This solution requires not only the joint work of legal practitioners, economists, sociologist and IT experts, software developers as only together may it be delimited the beacons of all content to be made available on the portal; It would be necessary to determine which information, from among all that which is available in a legitimate manner, is to be made available on the portal, subject to a careful scrutiny, avoiding superfluous and redundant availability for the placement of any and all information related to governmental activity may become counterproductive.

It is preferable to join efforts on showing the governing nature and allowing a serious and fair scrutiny of the activities taking into account with the sole discretion of the state. In fact, the State power is inaccurate because the law, sometimes, has loopholes that allow free interpretations and appreciation of the elements, which is acceptable, since the legislator, as is creating the law is yet unable to know all the situations where the law shall be applied. Thus, discretion is the opening of the legal standard to the Administration, greater freedom of action, allowing to choose the own ways of acting. This reality must be taken into account when establishing criteria. It is important to create pre-determined applying pragmatic, clear and achievable criteria mechanisms to make a consistent selection of the aims of the website, which are the definition of the treatment to be given to all gathered information, including financial arrangements facing public policy models, valuation models of public performance indicators of transparency and barometers mediation and time tracking. After being set, the framework for the information is to be made available, allowing the creation of exchange strategies with other existing platforms.

Finally, e-government transparency initiatives should also consider the implementation of monitoring mechanisms provided by independent organizations, such as non-governmental organizations or universities and research centers. The regular provision of functioning reports may help to overcome difficulties and identity gaps in the fulfilment of the platform mission.

\section{$5 \quad$ Conclusion}

Transparency has become a fashionable concept and the internet has expanded the ways in which it can be addressed. But transparency has to be much more than a rhetoric discourse of public officials that merely follow international trendy 

Mirage?

"winds" without fully addressing its consequences. Corruption is high in the political and international agenda, pushing politics to action. The Internet does provide citizens with far greater potential to monitor government, opening up mechanisms that enhance public scrutiny. It allows ordinary citizens to make their own judgements and assessments. But much more has still to be done.

Access and the awareness of how to effectively use such information as aspects that have to be developed and people need to be educates on how to access and use it. Such usability, functionality and accessibility require designing effective communications, paying attention to balancing the complexity that citizens can manage and the complexity that those responsible for the requested information are producing.

Public officials should not only rely in a mere disposal of information. This information has to be treated and presented in a way that makes sense to the ordinary citizen and in a way that is useful to him. Clearly, digital and technological transparency is the way to move forward on this purpose, but it may remain an asset for the elite only, for the educated ones and technologically skilled one. Thus an interdisciplinary approach is needed, not only to disclose information but also to 'tool up' citizens or to develop intermediaries that can provide bridges of understanding.

The mere disposal of information is not enough, as much of public documents suffer from complex language and other technicalities that can prevent an informed use of the information. Thus, sites displaying information must be adapted in order to guarantee usability, functionality and accessibility; there must be different levels of information, as there are diverse groups of individuals with different skills.

\section{Notes:}

${ }^{1}$ Law Decree $n .^{\circ} 48 / 95,15^{\text {th }}$ of March available online at :

http://www.pgdlisboa.pt/leis/lei_mostra_articulado.php?artigo_id=109A0374\&nid=109\&ta bela=leis\&pagina $=1 \&$ ficha $=1 \&$ so_miolo $=\&$ nversao $=\#$ artigo $($ accessed December 2016)

${ }^{2}$ Corruption is the misuse of official positions to obtain unofficial results, usually personal advantages, but often only benefit of the company itself or political party comes out of it. It may occur within public or private organizations, may include acts of omission or actions, may be internal to an organization or involve clients of the organization. Analogous to other social problems such as pollution or an epidemic, corruption may be divided into levels. It exists almost everywhere and its depth differs, as the social difference that it causes in each case differs. Corruption is a calculated crime. It is not the product of a moment of passion (...) Corruption $=$ monopoly + discretion - obligation to account Author's translation

${ }^{3}$ Council of Europe Convention on Access to Official Documents 2009, ETS 205. The Convention on Access to Official Documents will enter into force when ratified by ten states; to date it has been ratified by six and signed by a further eight. 
${ }^{4}$ XYZ v Victoria Police (General) [2010] VCAT 255 (16 March 2010) available online at: http://www.right2info.org/resources/publications/case-pdfs/australia_xyz-v-victoria-police accessed December 2016

${ }^{5} \mathrm{https}: / / \mathrm{www}$. portalmunicipal.pt/home?locale $=\mathrm{pt}$

${ }^{6} \mathrm{http}: / /$ poderlocal.transparencia.pt/

${ }^{7}$ (http://usaspending.gov/;http://wheredoesmymoneygo.org/http://transparencia.gob.es/)

\section{References}

Alcaide-Muñoz, L., \& Rodríguez Bolívar, M. (2015) Determining Factors of Transparency and Accountability in Local Governments: A Meta-Analytic Study, Lex Localis Journal Of Local Self-Government, 13(2), pp. 129-160, https://doi.org/10.4335/13.2.129-160(2015)

Ananiev, J., \& Poposka, Z. (2014) Participation and Anti-Discrimination Based Local Strategic Documents - Case of Macedonian Municipalities, Lex Localis - Journal of Local Self-Government, 12(3), pp. 575-590, https://doi.org/10.4335/12.3.575590(2014).

Anderson, T. B. (2009) E-government as an anti-corruption strategy, Information Economics and Policy, 21(3), pp. 201-210, https://doi.org/10.1016/j.infoecopol.2008.11.003.

Bannister, F. \& Connolly, R. (2011) The trouble with transparency: A critical review of Openness in e-Government, Policy and Internet, 3(1), 1-30, https://doi.org/ 10.2202/1944-2866.1076.

Bertot, J. C.; Jaeger, P. T. \& Grimes, J. M. (2010) Using ICTs to create a culture of transparency: E-government and social media as openness and anti-corruption tools for societies, Government Information Quarterly, 27(3), pp. 264-271, https://doi.org/10.1016/j.giq.2010.03.001.

Coglianese, C. (2009) The transparency President? Obama Administration and Open Government, Governance: an International Journal of Policy, Administration and Institutions, 22(4), pp. 529-544.

Cullier, D. \& Piotrowski, S. J. (2009) Internet information-seeking and its relation to support for access to government records, Government Information Quarterly, 26(3), pp. 441-449, https://doi.org/10.1016/j.giq.2009.03.001.

Jaeger, P. T. \& Bertot, J. C. (2010) Transparency and technological change: ensuring equal and sustained public access to government information, Government Information Quarterly, 27(4), pp. 371-376, https://doi.org/10.1016/j.giq.2010.05.003.

Harrison, T. M., \& Sayogo, D. S. (2014) Transparency, participation, and accountability practices in open government: A comparative study, Government Information Quarterly, 31(4), pp. 513-525.

Kierkegaard, S. (2009) Open access to public documents - more secrecy, less transparency!, Computer Law \& Security Review, 25(1), pp. 3-27, https://doi.org/10.1016/j.clsr.2008.12.001.

Margetts, H. (2011) The internet and transparency, The Political Quarterly, 82(4), pp. 518521.

Matheus, R.; Ribeiro, M. M.; Vaz, J. C. \& Souza, C. A. (2010) Using internet to promote the transparency and fight corruption: Latin America Transparency Portals, ICEGOV2010, October 25-28, Beijing, China. 
N. Bessa Vilela, J. C. Gomes \& P. Morais: Government Transparency: Reality or Mirage?

Meijer, A. J. (2012) Introduction to the special issue on government transparency, International Review of Administrative Sciences, 78(1), pp. 3-9.

Meijer, A. J.; Curtin, D. \& Hillebrandt, M. (2012) Open Government: connecting vision and voice, International Review of Administrative Sciences, 78(1), pp. 10-29.

Piotrowski, S. \& Van Ryzen, G. G. (2007) Citizen Attitudes toward transparency in local government, The American Review of Public Administration, 37(3), pp. 306-323.

Puron-Cid, G. (2013) Interdisciplinary application of structuration theory for e-government: A case study of an IT-enabled budget reform, Government Information Quarterly, 30(Supplement 1), pp. S46-S58, https://doi.org/10.1016/j.giq.2012.07.010.

Puron-Cid, G. (2014) Factors for a successful adoption of budgetary transparency innovations: A questionnaire report of an open government initiative in Mexico, Government Information Quarterly, 31(Supplement 1), pp. S49-S62, https://doi.org/10.1016/j.giq.2014.01.007.

Relly, J. E. \& Sabharwal, M. (2009) Perceptions of transparency of government policymaking: A cross-national study, Government Information Quarterly, 26(1), pp. 148-157, https://doi.org/10.1016/j.giq.2008.04.002.

Roberts, A. (2006) Blacked-out: Government secrecy in the information age (New York: Cambridge University Press).

Solana, M. (2004) Transparency portals: delivering public financial information to citizens in Latin America, in Thinking Out Loud V-Innovative case studies on participatory instruments (World Bank: Washington).

Triães, J. (2011) Acesso à informação, Media e corrupção em Portugal, In: De Sousa, L. \& Soares, D. (eds.) Transparência, Justiça e Liberdade. Em memória de Saldanha Sanches (Cascais: RCP Edições), p. 177. 